\title{
Increased risk for lung cancer and for cancer of the gastrointestinal tract among Geneva professional drivers
}

\author{
E Gubéran, M Usel, L Raymond, J Bolay, G Fioretta, J Puissant
}

\begin{abstract}
A historical prospective cohort study of 6630 drivers from the Canton of Geneva was carried out to evaluate mortality and incidence of cancer in this occupation. The study population was all men (of all vocations) who held in 1949 a special licence for driving lorries, taxis, buses, or coaches and all new licence holders in the period 1949-61. Men born before 1900 and those with only an ordinary driving licence were excluded. According to the occupation registered on their licence, the 6630 drivers were distributed into three groups: (1) professional drivers $(n=1726)$, (2) non-professional drivers "more exposed" to exhaust gas and fumes (this group included occupations such as vehicle mechanic, policeman, road sweeper; $n=712$ ), and (3) non-professional drivers "less exposed," composed of all other occupations $(n=4192)$. The cohort was followed up from 1949 to December 1986 and the trace of 197 men (3\%) was lost. Compared with the general population of the Canton of Geneva, professional drivers experienced significant excess risks, taking into account 15 years of latency, for all causes of death (standardised mortality ratio (SMR) $115,90 \%$ confidence interval $(90 \%$ CI) 107-123) and for all malignant neoplasms (SMR 125, 90\% CI 112-140; standardised incidence ratio (SIR) 128, $90 \%$ CI 115-142). Cause specific analysis showed significant excesses for lung cancer (SMR 150, $90 \%$ CI 123-181; SIR 161, 90\% CI 129-198), oesophageal cancer (SMR 183, 90\% CI 108-291), stomach cancer (SMR 179, 90\% CI 117-263; SIR 233, 90\% CI 156-336), rectal cancer (SMR 258, 90\% CI 162-392; SIR $200,90 \%$ CI 127-300), and cirrhosis of the liver
\end{abstract}

Geneva Medical Inspectorate of Factories, CH-1207 Geneva, Switzerland

E Gubéran, M Usel, J Bolay, J Puissant

Geneva Cancer Registry, CH-1205 Geneva, Switzerland

L Raymond, G Fioretta
(SMR 145, 90\% CI 104-198). Risk of lung cancer increased significantly with time from first exposure. Among non-professional drivers no significant excess risk was found except for lung cancer mortality among the "less exposed" group (SMR 121, 90\% CI 103-140), and for incidence of lung cancer among the "more exposed" group (SIR 161, 90\% CI 111-227). The possible causal relation between exposure to engine exhaust emissions and the increased risk for lung caricer and for cancer of the gastrointestinal tract found among professional drivers is discussed.

Recently, the International Agency for Research on Cancer (IARC) has critically reviewed evidence for carcinogenicity of engine exhaust fumes provided by epidemiological studies, experimental studies in animals, and other relevant biological data. ${ }^{1}$ In the overall evaluation it has been concluded that diesel exhaust fumes are "probably carcinogenic" to humans and petroleum exhaust fumes are "possibly carcinogenic".

The purpose of the present study was to investigate the risk of cancer among a cohort of professional and non-professional drivers from the Canton of Geneva.

\section{Population and methods}

The card index records of all vehicle licences that were valid in 1949 and all licences issued between 1949 and 1961 have been stored in the archives of the Cantonal licencing authorities in Geneva. The following categories were not considered: women drivers of all ages, and holding all categories of licence; all men born before 1900, and also men born after this date, holding only normal private driving licences. The base cohort was therefore composed of 6721 men (of all vocations) born from 1900 onwards and having obtained at least one of the following special licences: for heavy duty road goods vehicles (>3.5 tonnes), for taxis, buses, and coaches, and for light duty road passenger vehicles (vehicles of less 
Table 1 Number of drivers by occupational category, type of driving licence, and issue date of the licence

\begin{tabular}{|c|c|c|c|c|c|c|}
\hline \multirow[b]{3}{*}{ Type of licence and issue date } & \multirow{2}{*}{\multicolumn{2}{|c|}{ Professional drivers }} & \multicolumn{4}{|c|}{ Non-professional drivers } \\
\hline & & & \multicolumn{2}{|c|}{ "More exposed"» } & \multicolumn{2}{|c|}{ "Less exposed"† } \\
\hline & No & $\%$ & No & $\%$ & No & $\%$ \\
\hline $\begin{array}{l}\text { Lorry } \\
\text { Taxi, chauffeur } \\
\text { Bus, coach }\end{array}$ & $\begin{array}{r}1278 \\
128 \\
320\end{array}$ & $\begin{array}{r}74 \cdot 0 \\
7 \cdot 4 \\
18 \cdot 5\end{array}$ & $\begin{array}{r}683 \\
21 \\
8\end{array}$ & $\begin{array}{r}95.9 \\
2.9 \\
1 \cdot 1\end{array}$ & $\begin{array}{r}3790 \\
381 \\
21\end{array}$ & $\begin{array}{r}90 \cdot 4 \\
9 \cdot 1 \\
0.5\end{array}$ \\
\hline Total & 1726 & $100 \cdot 0$ & 712 & $100 \cdot 0$ & 4192 & $100 \cdot 0$ \\
\hline $\begin{array}{l}\text { Licence in } 1949-61 \\
\text { Licence before } 1949\end{array}$ & $\begin{array}{l}818 \\
908\end{array}$ & & $\begin{array}{l}392 \\
320\end{array}$ & & $\begin{array}{l}2559 \\
1633\end{array}$ & \\
\hline
\end{tabular}

*Ambulance men, policemen, firemen, vehicle mechanics and other garage workers, petrol pump attendants, refuse collectors, roadsweepers, earth moving equipment operators, driving school drivers, occupations with the term of driver and any other profession (for example, driver-electrician).

†All other occupations.

than 3.5 tonnes for professional transport of more than eight passengers).

Seventy seven French drivers residing in the French regions bordering Geneva canton were eliminated as well as eight Swiss and six foreign drivers who resided in Geneva according to their licence but who could not be located in the records of the Geneva Population Office. The 6630 men remaining constituted the study cohort.

According to the occupation registered on their licence, the men were divided into professional and non-professional drivers (table 1). Among the second group, a "more exposed" group was constituted on the basis of occupations (listed under table 1) presumed to be more exposed than average to exhaust gas. The "less exposed" group was composed of all other occupations, although those which may necessitate a lorry such as market gardener, butcher, carpenter-joiner, or storeman were overrepresented, as was the occupation of student. When the occupation registered was only "professional driver" without specification of the type of driving, and the driver had obtained several special licences, the following rules were used: drivers with a licence for a lorry and one or several other special licences were classified as lorry drivers; similarly those with a licence for bus or coach, and a licence for taxi or light duty road passenger vehicles were classified in the category "taxi driver or chauffeur."

The 6630 men were traced from the date of issue of their driving licence if it occurred in 1949-61, or from 1 January 1949 if it occurred before 1949 , up to 31 December 1986 (4500 alive), or to their death (1933), or to the date at which their trace was lost (197; 3\%), according to methods previously described. ${ }^{2}$ Mortality was studied from 1 January 1949 to 31 December 1986. The official death certificate codings were supplied by the National Office of Statistics for all men who died in Switzerland, except two whose certificates could not be found. Among the
70 men who died in foreign countries, the cause of death was obtained from a foreign authority for 17, from the attending physician for three, from a Geneva newspaper for one (a mountain accident), and it remained unknown for 49. Expected deaths were calculated with the "man years computer language" program ${ }^{3}$ using age and year specific regional rates.

Incidence of cancer was analysed from 1 January 1970 (the date of the start of the Geneva Cancer Registry) to 31 December 1986 among the 5014 drivers who lived in the canton of Geneva during that period. Expected cases of cancer were calculated using mean age specific incident rates of the Geneva male population for three periods: $1970-5,1976-81$ and 1982-6.

The one sided significance of an excess of observed deaths or cancer cases was calculated by the usual methods based on the Poisson distribution. Tests for homogeneity and for trend in the SMRs were made using the methods described by Breslow and Day. ${ }^{4}$

\section{TRENDS IN GENEVA TRAFFIC DENSITY}

In the canton of Geneva (1986 population 370000 ) the number of registered motor vehicles has steadily risen from about 25000 units (of which 2800 were lorries) in 1950 to about 223000 (10 800 lorries) in 1986 , corresponding to an increase from 12 to 60 vehicles per 100 population. For decades the density of traffic in the city and canton of Geneva has been higher than in other Swiss cities and cantons, and than in most other European cities. Moreover, the first diesel powered lorries (from the firm Daimler) first started service in 1928 , becoming more widely used during the 1950s and 60s.

\section{EXPOSURE OF GENEVA LORRY DRIVERS}

From information collected on professional drivers in various registers, it could be estimated that nearly half did not move to another occupation, at least 
before the age of $55-60$. Probably between one quarter and one third of lorry drivers were engaged in medium or long distance freight haulage. The others worked within the canton in the transport of materials to be used principally in the construction industry.

Although in the 1950s and 60s the volume of traffic in Geneva was much less than today, it is likely that a substantial minority of drivers of older lorries were exposed, to a certain extent, to the exhaust fumes of their own vehicles. According to experts of the Geneva licencing authorities, lorries from the firms Ford, Citroen, and Bedford had their exhaust under the cab, as was reported in other countries. ${ }^{5}$ Exhaust emissions could easily penetrate the cab through the wooden floor because of the leaks around the gear lever and the pedals. The number of such lorries has diminished progressively since the 1962 regulation that imposed an exhaust outlet at the back left hand side of all new lorries. For this type of lorry, the driver was exposed to the emissions from other vehicles, mainly petroleum driven cars, as is any driver in road traffic. Exposure of the driver to the diesel exhaust fumes of his own lorry might occur on rare occasions, such as when running the engine at standstill, with a strong following wind. Exposure to the exhaust emissions of other lorries would also occur when the drivers had to queue, for instance in the delivery of materials to building sites.

In possible relation to the "healthy worker effect", it should be mentioned that since 1933, all candidates for special licences have had to produce proof of fitness to drive, in the form of a medical certificate established by an expert appointed by the licencing authorities. Periodic medical examinations are compulsory every five years, up to the age of 50 years, and every three years thereafter. No medical examination has been required for the acquisition or maintenance of normal private licences.

SMOKING AMONG SWISS DRIVERS

The only available data on smoking among Swiss professional drivers were not collected in Geneva, but in the neighbouring cantons of Vaud and Fribourg. In the framework of a multicentric study on risk factors for vascular disease coordinated by the World Health Organisation, ${ }^{6}$ two random population samples were drawn in 1984-5 and in 1988-9. Smoking habits were collected among a total of 1782 men aged 25 to 64 , of whom 50 were professional drivers. There were $46 \%$ current cigarette smokers among drivers $(95 \%$ confidence interval $(95 \% \mathrm{CI})$ $32 \%-61 \%$ ) compared with $35 \%$ among all other professions. For heavy smokers $(\geqslant 25$ cigarettes a day) the proportions were respectively $22 \%$ (95\% CI $12 \%-36 \%$ ) and $13 \%$. These differences were not statistically significant, but the number of drivers was small.

\section{Results}

OVERALL COHORT AND MAIN GROUPS

A total of 198667 man-years were contributed by the study cohort. Overall mortality of the cohort was similar to that expected from Geneva rates: observed deaths (Obs) 1933, expected deaths (Exp) 1923.1, standardised mortality ratio (SMR) $101,90 \%$ confidence interval $(90 \% \mathrm{CI})$ 97-104. Mortality during the first 15 years since the date of the licence (Obs 188, Exp 243.3, SMR 77, 90\% CI 68-87) was significantly lower than that of the remaining period (Obs 1745, Exp 1679.8, SMR 104, 90\% CI 100-108). In view of this "healthy worker effect" a latency of 15 years was included in our analysis of mortality and incidence of cancer.

Moreover, mortality was compared between all men traced from the date of issue of their driving licence in 1949-61, and those traced from 1 January 1949 who were the "survivors" of the drivers who had obtained their licence in the decades before 1949. Taking into account 15 years of latency, the SMR from all causes was 110 among the first $(90 \% \mathrm{CI} 102-$ 118, Obs 538, Exp 490.9) and 102 among the second (90\% CI 97-106, Obs 1207, Exp 1188.9), which represents a non-significant difference. As the

Table 2 Mortality $1949-86$ from all causes and from the leading categories of deaths, allowing for 15 years of latency, among the three main groups of drivers

\begin{tabular}{|c|c|c|c|c|c|c|c|}
\hline \multirow[b]{3}{*}{ Cause of death (ICD-8) } & \multicolumn{4}{|c|}{ Non-professional drivers } & & & \multirow{3}{*}{$\begin{array}{l}\text { Test for } \\
\text { trend } \\
(p \text { Value })\end{array}$} \\
\hline & \multicolumn{2}{|c|}{ "Less exposed" group $\dagger$} & \multicolumn{2}{|c|}{ "More exposed" groupt } & \multicolumn{2}{|c|}{ Professional drivers } & \\
\hline & Obs & $S M R(90 \% C I)$ & Obs & $\operatorname{SMR}(90 \% C I)$ & Obs & $\operatorname{SMR}(90 \% C I)$ & \\
\hline \multirow{2}{*}{$\begin{array}{l}\text { All causes (000-999) } \\
\text { Malignant neoplasms }(140-209) \\
\text { Circulatory disease }(390-458) \\
\text { Violent deaths (E 800-999) } \\
\text { All other causes }(0-136,210-389 \text {, } \\
460-796) \\
\text { Unknown cause }\end{array}$} & $\begin{array}{r}983 \\
336 \\
348 \\
64\end{array}$ & $\begin{aligned} & 98(93-104) \\
& 99(90-108) \\
& 101(92-110) \\
& 77(62-95)\end{aligned}$ & $\begin{array}{r}176 \\
62 \\
58 \\
16\end{array}$ & $\begin{array}{l}103(91-117) \\
106(85-131) \\
100(80-125) \\
109(68-165)\end{array}$ & $\begin{array}{r}586 \\
214 \\
205 \\
38\end{array}$ & $\begin{array}{cc}115^{\star \star \star} & (107-123) \\
125^{\star \star \star} & (112-140) \\
114^{\star} & (102-128) \\
98 & (74-129)\end{array}$ & $\begin{array}{l}<0.01 \\
<0.01 \\
\text { NS } \\
\text { NS }\end{array}$ \\
\hline & $\begin{array}{r}205 \\
30\end{array}$ & $88(79-99)$ & $\begin{array}{r}35 \\
5\end{array}$ & $88(65-116)$ & $\begin{array}{r}115 \\
14\end{array}$ & $(80-110)$ & NS \\
\hline
\end{tabular}

${ }^{\star} \mathrm{p}<0.05 ;{ }^{\star \star \star} \mathrm{p}<0.001 .+$ See footnote to table 1 .

NS = Not significant; ICD-8 = eighth revision of the International Classification of Diseases. 
"survivor bias" had a limited influence on the mortality of the second group, it was decided to pool these two groups.

No significant increase in mortality from all causes and from the leading categories of deaths occurred among the two groups of non-professional drivers; whereas mortality from all causes, from all malignant neoplasms, and from circulatory disease was significantly in excess among professional drivers. A significant upward trend was seen for mortality from all causes and from all malignant neoplasms when going from the "less exposed" group of non-professional drivers to the group of professional drivers (table 2).

Analysis of cause specific mortality and incidence of cancer among the two groups of non-professional drivers (not in table) showed no significantly increased risk except for lung cancer. A significant increase in lung cancer mortality among the "less exposed" group (SMR 121, 90\% CI 103-140), and a significant increase in incidence of lung cancer among the "more exposed" group (standardised incidence ratio (SIR) 161, 90\% CI 111-227) were found (see table 5).

\section{PROFESSIONAL DRIVERS}

Table 3 shows the cancer mortality and incidence of cancer among professional drivers. There was a significantly increased risk for lung cancer, and for three sites of the gastrointestinal tract-namely, the oesophagus, stomach, and rectum. No significant increase was found for colon cancer, for which mortality (SMR 92) was significantly different ( $p<$ 0.01 ) from that of rectal cancer (SMR 258). Further analysis of the four cancer sites with a significant excess risk was carried out by age and by calendar period, and no significant trend was seen for mortality or incidence.

Altogether 33 deaths or incident cases of stomach cancer were found. Data from the Geneva Cancer Registry on men indicate a relative risk for this cancer of 3.0 for the natives of Italy, and of 5.3 for the natives of Spain, residing in the canton, compared with the natives of Geneva. ${ }^{7}$ Inquiries were made on the place of birth of the 33 professional drivers who had a stomach cancer. Only two (6\%) were born in Italy or Spain, a proportion lower than that recorded during the study period among the population of the canton of Geneva.

Among the non-malignant causes of death in professional drivers (table 4) only mortality from cirrhosis of the liver was significantly higher than expected. Despite a significant increase in mortality from circulatory disease, no subcategory showed a significant excess of death, especially ischaemic heart disease (SMR 104). Mortality from chronic bronchitis and emphysema was similar to that expected, and mortality from motor vehicle accidents was increased (SMR 147) but not significantly.

\section{TREND WITH LEVEL OF EXPOSURE}

The average level of exposure to exhaust gas and fumes was very likely higher in the "more exposed" group than in the "less exposed" group of nonprofessional drivers, and highest among professional drivers. A significant trend from the least exposed to the most exposed category was seen for mortality from stomach cancer and rectal cancer, and for the incidence of stomach cancer, rectal cancer, and lung cancer (table 5).

Table 3 Professional drivers. Cancer mortality $1949-86$ and cancer incidence 1970-86 for selected sites, allowing for 15 years of latency

\begin{tabular}{|c|c|c|c|c|c|c|c|c|}
\hline \multirow[b]{2}{*}{ Site of cancer (ICD-8) } & \multicolumn{4}{|c|}{ Deaths $1949-86$} & \multicolumn{4}{|c|}{ Cases of cancer $1970-86$} \\
\hline & Obs & $\operatorname{Exp}$ & $S M R$ & $90 \%(C I)$ & Obs & $\operatorname{Exp}$ & $\operatorname{SIR}(9$ & $90 \%(C I)$ \\
\hline $\begin{array}{l}\text { All malignant neoplasms }(140-209) \\
\text { Buccal cavity, pharynx (140-149) } \\
\text { Oesophagus (150) } \\
\text { Stomach (151) } \\
\text { Colon (153) } \\
\text { Rectum (154) } \\
\text { Liver (155) } \\
\text { Gallbladder (156) } \\
\text { Pancreas (157) } \\
\text { Larynx (161) } \\
\text { Lung (162) } \\
\text { Melanoma (172) } \\
\text { Skin, other malignant (173) } \\
\text { Prostate (185) } \\
\text { Bladder (188) } \\
\text { Kidney and other urinary organs (189) } \\
\text { Lymph/haemopoietic (200-209) } \\
\text { Leukaemia (204-207) } \\
\text { Others and unknown }\end{array}$ & $\begin{array}{r}214 \\
12 \\
13 \\
19 \\
10 \\
16 \\
6 \\
2 \\
7 \\
5 \\
77 \\
0 \\
1 \\
12 \\
11 \\
2 \\
11 \\
6 \\
10\end{array}$ & $\begin{aligned} 170 \cdot 7 \\
8 \cdot 9 \\
7 \cdot 1 \\
10 \cdot 6 \\
10 \cdot 9 \\
6 \cdot 2 \\
6 \cdot 8 \\
1 \cdot 7 \\
7 \cdot 7 \\
4 \cdot 5 \\
51 \cdot 4 \\
1 \cdot 9 \\
0 \cdot 9 \\
14 \cdot 0 \\
7 \cdot 7 \\
4 \cdot 5 \\
11 \cdot 9 \\
4 \cdot 6 \\
14 \cdot 0\end{aligned}$ & $\begin{array}{l}125^{\star \star \star} \\
135 \\
183^{\star} \\
179^{\star} \\
92 \\
258^{\star \star \star} \\
88 \\
118 \\
91 \\
111 \\
150^{\star \star \star} \\
111 \\
86 \\
143 \\
44 \\
92 \\
130 \\
71\end{array}$ & $\begin{array}{r}(112-140) \\
(78-218) \\
(108-291) \\
(117-263) \\
(50-156) \\
(162-392) \\
(38-174) \\
(21-370) \\
(43-171) \\
(44-234) \\
(123-181) \\
(0-158) \\
(6-527) \\
(49-139) \\
(80-236) \\
(8-140) \\
(52-153) \\
(57-257) \\
(39-121)\end{array}$ & $\begin{array}{r}251 \\
15 \\
7 \\
21 \\
14 \\
17 \\
3 \\
4 \\
3 \\
4 \\
64 \\
6 \\
36 \\
25 \\
13 \\
4 \\
7 \\
5 \\
8\end{array}$ & $\begin{array}{r}196 \cdot 4 \\
12 \cdot 1 \\
4 \cdot 4 \\
9 \cdot 0 \\
12 \cdot 6 \\
8 \cdot 5 \\
6 \cdot 2 \\
1 \cdot 4 \\
5 \cdot 1 \\
5 \cdot 2 \\
39 \cdot 8 \\
3 \cdot 2 \\
28 \cdot 6 \\
21 \cdot 9 \\
10 \cdot 4 \\
5 \cdot 4 \\
9 \cdot 9 \\
4 \cdot 1 \\
12 \cdot 6\end{array}$ & $\begin{array}{l}128 \star \star \star \\
124 \\
159 \\
233^{\star \star \star} \\
111 \\
200^{\star \star} \\
48 \\
286 \\
59 \\
77 \\
161 \star \star \star \\
187 \\
126 \\
114 \\
125 \\
74 \\
71 \\
122 \\
63\end{array}$ & $\begin{array}{r}(115-142) \\
(76-191) \\
(75-299) \\
(156-336) \\
(67-174) \\
(127-300) \\
(13-125) \\
(98-654) \\
(16-152) \\
(26-176) \\
(129-198) \\
(82-370) \\
(93-166) \\
(79-159) \\
(74-199) \\
(25-170) \\
(33-133) \\
(48-256) \\
(32-115)\end{array}$ \\
\hline
\end{tabular}

${ }^{\star} \mathrm{p}<0.05 ;{ }^{\star \star} \mathrm{p}<0.01 ;{ }^{\star \star \star} \mathrm{p}<0.001$. 
Table 4 Professional drivers. Mortality 1949-86 from selected non-malignant causes, allowing for 15 years of latency

\begin{tabular}{|c|c|c|c|c|}
\hline Cause of death (ICD-8) & Obs & $E x p$ & \multicolumn{2}{|c|}{$S M R(90 \% C I)$} \\
\hline $\begin{array}{l}\text { Hypertension (400-404) } \\
\text { Ischaemic heart disease }(410-414) \\
\text { Other heart diseases }(390-398,420-429) \\
\text { Cerebrovascular disease }(430-438) \\
\text { Other circulatory diseases }(440-458) \\
\text { Chronic bronchitis, emphysema (491, 492) } \\
\text { Peptic ulcer (531-533) } \\
\text { Cirrhosis of liver (571) } \\
\text { Alcoholism (291, 303, E 860) } \\
\text { Motor vehicle accident (E 810-823) } \\
\text { Other accidents and poisonings (E 800-807, 825-949) } \\
\text { Suicide (E 950-959) }\end{array}$ & $\begin{array}{r}6 \\
68 \\
75 \\
37 \\
19 \\
12 \\
4 \\
29 \\
2 \\
14 \\
12 \\
11\end{array}$ & $\begin{array}{r}5 \cdot 3 \\
65 \cdot 4 \\
66 \cdot 8 \\
28 \cdot 0 \\
13 \cdot 8 \\
11 \cdot 1 \\
4 \cdot 1 \\
20 \cdot 0 \\
2 \cdot 4 \\
9 \cdot 5 \\
13 \cdot 2 \\
15 \cdot 3\end{array}$ & $\begin{array}{r}113 \\
104 \\
112 \\
132 \\
138 \\
108 \\
98 \\
145^{\star} \\
83 \\
147 \\
91 \\
72\end{array}$ & $\begin{array}{r}(49-223) \\
(84-127) \\
(92-136) \\
(99-174) \\
(90-202) \\
(62-175) \\
(33-223) \\
(104-198) \\
(15-262) \\
(89-230) \\
(52-147) \\
(40-119)\end{array}$ \\
\hline
\end{tabular}

${ }^{\star} \mathrm{p}<0.05$.

Table 5 Cancer mortality 1949-86 and cancer incidence 1970-86 for selected sites, allowing for 15 years of latency, among the three main groups of drivers

\begin{tabular}{|c|c|c|c|c|c|c|c|c|c|}
\hline \multirow{4}{*}{$\begin{array}{l}\text { Site of cancer (ICD-8) } \\
\text { Stomach (151): } \\
\text { Deaths } \\
\text { Incident cases }\end{array}$} & \multicolumn{6}{|c|}{ Non-professional drivers } & & & \multirow{3}{*}{$\begin{array}{l}\text { Test for } \\
\text { trend } \\
\text { ( } p \text { Value })\end{array}$} \\
\hline & \multicolumn{3}{|c|}{ "Less exposed" group } & \multicolumn{3}{|c|}{ "More exposed" group } & \multicolumn{2}{|c|}{ Professional drivers } & \\
\hline & Obs & $S M I$ & $(90 \% C I)$ & Obs & $S M I$ & $(90 \% C I)$ & Obs & $S M R(90 \% C I)$ & \\
\hline & $\begin{array}{l}18 \\
16\end{array}$ & $\begin{array}{l}91 \\
87\end{array}$ & $\begin{array}{l}(59-135) \\
(55-133)\end{array}$ & $\begin{array}{l}3 \\
3\end{array}$ & $\begin{array}{l}88 \\
97\end{array}$ & $\begin{array}{l}(24-228) \\
(26-250)\end{array}$ & $\begin{array}{l}19 \\
21\end{array}$ & $\begin{array}{ll}179^{\star} & (117-263) \\
233^{\star \star \star} & (156-336)\end{array}$ & $\begin{array}{l}<0.05 \\
<0.01\end{array}$ \\
\hline $\begin{array}{l}\text { Rectum (154): } \\
\text { Deaths } \\
\text { Incident cases }\end{array}$ & $\begin{array}{r}7 \\
15\end{array}$ & $\begin{array}{l}60 \\
87\end{array}$ & $\begin{array}{l}(28-112) \\
(53-134)\end{array}$ & $\begin{array}{l}1 \\
5\end{array}$ & $\begin{array}{r}50 \\
167\end{array}$ & $\begin{array}{r}(3-237) \\
(66-350)\end{array}$ & $\begin{array}{l}16 \\
17\end{array}$ & $\begin{array}{ll}258^{\star \star \star} & (162-392) \\
200^{\star \star} & (127-300)\end{array}$ & $\begin{array}{l}<0.001 \\
<0.05\end{array}$ \\
\hline $\begin{array}{l}\text { Lung (162): } \\
\text { Deaths } \\
\text { Incident cases }\end{array}$ & $\begin{array}{r}126 \\
97\end{array}$ & $\begin{array}{l}121^{\star} \\
115\end{array}$ & $\begin{array}{l}(103-140) \\
(97-137)\end{array}$ & $\begin{array}{l}24 \\
24\end{array}$ & $\begin{array}{l}132 \\
161^{\star}\end{array}$ & $\begin{array}{r}(91-185) \\
(111-227)\end{array}$ & $\begin{array}{l}77 \\
64\end{array}$ & $\begin{array}{l}150^{\star \star \star}(123-181) \\
161^{\star \star \star}(129-198)\end{array}$ & $\begin{array}{l}\text { NS } \\
<0.05\end{array}$ \\
\hline
\end{tabular}

${ }^{\star} \mathrm{p}<0.05 ;{ }^{\star \star} \mathrm{p}<0.01 ;{ }^{\star \star \star} \mathrm{p}<0.001$.

Table 6 Professional drivers. Mortality from lung cancer, from stomach cancer, from rectal cancer, and from all other malignant neoplasms, by time from first exposure

\begin{tabular}{|c|c|c|c|c|c|c|c|c|c|c|c|c|}
\hline \multirow{2}{*}{$\begin{array}{l}\text { Time from } \\
\text { first } \\
\text { exposure (y) }\end{array}$} & \multicolumn{3}{|c|}{ Lung cancer } & \multicolumn{3}{|c|}{ Stomach cancer } & \multicolumn{3}{|c|}{ Rectal cancer } & \multicolumn{3}{|c|}{$\begin{array}{l}\text { All other malignant } \\
\text { neoplasms }\end{array}$} \\
\hline & Obs & $\operatorname{Exp}$ & $S M R$ & Obs & $\operatorname{Exp}$ & $S M R$ & Obs & $E x p$ & $S M R$ & Obs & $E x p$ & $S M R$ \\
\hline $\begin{array}{l}0-14 \\
15-24 \\
25-34 \\
35-44 \\
15-\end{array}$ & $\begin{array}{r}2 \\
11 \\
24 \\
21 \\
21\end{array}$ & $\begin{array}{r}3 \cdot 0 \\
9 \cdot 3 \\
18 \cdot 5 \\
15 \cdot 5 \\
8 \cdot 1\end{array}$ & $\begin{array}{r}67 \\
118 \\
130 \\
135 \\
259\end{array}$ & $\begin{array}{l}2 \\
7 \\
3 \\
5 \\
4\end{array}$ & $\begin{array}{l}1 \cdot 1 \\
2 \cdot 2 \\
3 \cdot 5 \\
3 \cdot 0 \\
1 \cdot 9\end{array}$ & $\begin{array}{r}182 \\
318 \\
86 \\
167 \\
211\end{array}$ & $\begin{array}{l}0 \\
3 \\
1 \\
8 \\
4\end{array}$ & $\begin{array}{l}0 \cdot 4 \\
1 \cdot 1 \\
2 \cdot 0 \\
1 \cdot 9 \\
1 \cdot 2\end{array}$ & $\begin{array}{r}- \\
273 \\
50 \\
421 \\
333\end{array}$ & $\begin{array}{r}2 \\
13 \\
37 \\
38 \\
14\end{array}$ & $\begin{array}{r}8.5 \\
18 \cdot 0 \\
33 \cdot 2 \\
30.6 \\
20.7\end{array}$ & $\begin{array}{r}24 \\
72 \\
111 \\
124 \\
68\end{array}$ \\
\hline Test for trend & \multicolumn{3}{|c|}{$p<0.02$} & \multicolumn{3}{|c|}{ NS } & \multicolumn{3}{|c|}{ NS } & \multicolumn{3}{|c|}{ NS } \\
\hline
\end{tabular}

TREND WITH TIME FROM FIRST EXPOSURE

Table 6 shows that with increasing time from first exposure-that is, duration from the date of issue of the special driving licence-a significant upward mortality trend for lung cancer among professional drivers occurred. For the period of 45 years or more after first exposure, about half of the deaths from malignant neoplasms were due to lung cancer, whereas only a quarter would be expected. No significant mortality trend with time from first exposure was found for stomach cancer or rectal cancer, although the numbers within the time periods were small.

\section{HISTOLOGICAL TYPES OF LUNG CANCER}

Among professional drivers there were, altogether, 94 lung cancer deaths or incident cases that were histologically or cytologically confirmed. The dis- 
tribution of the major cell types of these 94 lung cancers was similar to that obtained among all Geneva men from the Geneva Cancer Registry for $1979-86(n=1204)$. There were $51 \cdot 1 \%$ and $51 \cdot 7 \%$ squamous cell carcinomas, $17.0 \%$ and $18.3 \%$ adenocarcinomas, $17.0 \%$ and $19.7 \%$ undifferentiated small cell carcinomas, $5.3 \%$ and $4.0 \%$ undifferentiated large cell carcinomas, and $9.6 \%$ and $6.4 \%$ mixed carcinomas or other tumours respectively.

\section{Discussion}

\section{LUNG CANCER}

A retrospective cohort study, very similar to ours, was carried out recently in London among 3392 professional drivers, of whom three quarters were lorry drivers. ${ }^{8}$ The $1950-84$ mortality was significantly raised for all malignant neoplasms $(S M R=122)$, stomach cancer $(S M R=130)$, and lung cancer ( $S M R=147$ ), although smoking was not controlled. In Sweden, incidence of lung cancer for the period 1961-79 was studied among 1.6 million men gainfully employed, and aged 30-64 in 1960.9 The increase found in risk of lung cancer among professional drivers $(S I R=132)$ based on 1021 cases, remained significant when adjusted for smoking ( $S I R=114,95 \% C I=103-125)$. In addition to these two well conducted cohort studies, four smoking adjusted case-control studies showed a significant association between professional driving and lung cancer. ${ }^{10-13}$ Overall evidence from these six studies seems to indicate an occupational risk factor, although other studies were negative. ${ }^{14}$

Among Geneva professional drivers smoking was not controlled. There was, however, no significantly increased risk for ischaemic heart disease, chronic bronchitis and emphysema, and smoking related cancers, other than lung cancer (buccal cavity and pharynx, pancreas, larynx, bladder, kidney). An exception was cancer of the oesophagus, probably due mainly to the increased consumption of alcohol as discussed later.

Thus, if indeed professional drivers in the study cohort smoked more than the reference population, as do professional drivers from other countries, ${ }^{95-17}$ the increase in tobacco consumption was probably too limited to account for the whole increase in risk of lung cancer.

On the other hand, the similarity in the distribution of lung cancer cell types between professional drivers and the Geneva male population is neither for nor against an occupational factor. This result is consistent with those of preceding studies ${ }^{131718}$ and with the more general lack of strong evidence of an association of a single lung cancer histological type with exposure to chemical or physical agents. ${ }^{19}$

Exposure to diesel and petroleum exhaust fumes is a biologically plausible risk factor of lung cancer. ${ }^{1}$ To support the role of this factor among Geneva professional drivers there was evidence of a significant upward trend of lung cancer mortality with longer time from the commencement of occupational exposure, which suggests a dose-response relation.

\section{OESOPHAGEAL CANCER}

Alcohol and tobacco are the main risk factors for oesophageal cancer..$^{20}$ An excess risk for alcohol abuse among Geneva professional drivers is strongly suggested by the significant increase in mortality from liver cirrhosis. Thus the significantly high mortality from cancer of the oesophagus may well be accounted for by alcohol, possibly in conjunction with smoking, although the limited role of an occupational factor cannot be ruled out.

\section{STOMACH CANCER}

By contrast with oesophageal cancer, there is no evidence that alcohol and tobacco affect the occurrence of stomach cancer, ${ }^{21}$ which might have explained our finding of an association between this cancer and professional driving. On the other hand, a number of studies have shown an association of stomach cancer with low socioeconomic class. ${ }^{21-23}$ Professional drivers belong to the social class of skilled manual workers ${ }^{8}$ whose mortality from stomach cancer was found to be only slightly above that for all men in Great Britain.22 There is no obvious reason why the situation should be different in Switzerland, although no data are available to confirm this. Also, we found no evidence of a cluster of men born in the high risk area of southern Europe among the drivers of the study cohort who had a stomach cancer.

There have been reports of an association of stomach cancer with dusty industries, and with air pollution, although evidence is equivocal. ${ }^{23}{ }^{24}$ The hypothesis is that particles containing carcinogens are inhaled, brought up through mucociliary clearance, and then swallowed. ${ }^{23}$ Particles emitted from petroleum engines and even more so, those from diesel engines, contain numerous polycyclic aromatic hydrocarbons, and are mutagenic in short term tests, and carcinogenic in several rodent species. ${ }^{1}$ Thus, the hypothesis of occupational exposure to account for the significant excess risk for stomach cancer among Geneva professional drivers is biologically plausible and is supported, as mentioned above, by the results of a similar cohort study in London. $^{8}$ No association was found, however, between mortality from stomach cancer and time from first exposure, which contrasts with the finding for lung cancer, although the numbers of deaths within the time periods were small (table 6).

RECTAL CANCER

Studies which distinguished sites within the large 
intestine have provided strong evidence of an increased risk for colon cancer, but not rectal cancer in sedentary jobs, ${ }^{25-28}$ the opposite of our findings. No general agreement exists, however, over the classification of lorry driving among sedentary occupations. ${ }^{25} 28$

Geneva professional drivers were probably more likely to abuse alcohol than the average population. Several epidemiological studies have suggested an association of rectal cancer with drinking alcoholic beverages, especially beer. ${ }^{20}$ According to the overall evaluation by IARC, however, evidence of this association is inconclusive, because of the inconsistent findings from epidemiological studies, and the probability of uncontrolled confounding by dietary factors. ${ }^{20}$

At the present state of knowledge, it is supposed that these dietary factors play the main part in the large variations in incidence of rectal cancer between, and within, countries. ${ }^{29}$ It cannot be ruled out that the dietary habits of Geneva professional drivers were different from those of the reference population; however, this possible difference is not likely to account for all of the high excess of deaths and incident cases from rectal cancer. On the other hand, the lack of an association with time from first exposure seems to exclude an occupational factor, although the numbers of observed and expected deaths (table 6) were too small to allow a meaningful conclusion.

As far as we know the only support for our results comes from the recent large "hypotheses generating" case-control study on occupational risk factors among the population of Montreal. ${ }^{30}$ There was a significant association of rectal cancer with professional driving (odds ratio (OR) $1 \cdot 5,90 \%$ CI 1.0-2.2) and with all occupations exposed to petroleum exhaust. For professional drivers a dose-response relation was seen with an OR of $1 \cdot 6(90 \%$ CI $1 \cdot 1-2 \cdot 3)$ in the "long high" exposure group.

\section{Conclusion}

In the present retrospective cohort study, it was not possible to control for smoking, alcohol consumption, and dietary habits. Confounding by these factors, however, does not seem to fully explain the highly significant excess risks for lung cancer, stomach cancer, and rectal cancer found among Geneva professional drivers. At least as far as lung cancer is concerned, our findings support the results of several epidemiological studies, and animal experiments, which showed that a risk of cancer is related to prolonged exposure to diesel or petroleum exhaust emissions.

We gratefully acknowledge the invaluable assistance of Mr P M Sweetnam, statistician from the MRC Epidemiology Unit, Cardiff. We thank Professor
H Savolainen (Lausanne), and Professor M A Cooke (Birmingham) for critically reading the manuscript, as well as Mr I D Hill (MCR Clinical Research Centre, Harrow) for providing the MYCL program. We are grateful to Dr T Spuhler from the "Office fédéral de la statistique", Mrs A Navarro and Mr $\mathrm{J}$ Heymoz from the "Service des automobiles," $\mathrm{Mr}$ $\mathrm{R}$ Mermoud and Mr M Jost from the "Fonds de Compensation AVS", and Mrs C Santschi from the "Archives d'Etat de Genève". We would like to thank for technical assistance Mr P Cabdy, and for help in data collection Mrs J Gorgé-Dubois, $\mathrm{Mr}$ L Collet, Mr S Gard, Mrs M Hagenbucher, Mr A Hunger, Mrs I Joncourt, Mr P Koeb, and Mrs M Reymond.

Requests for reprints to Dr E Gubéran, Service du médecin inspecteur du travail, 23 rue Ferdinand Hodler, CH-1207 Geneva, Switzerland.

1 International Agency for Research on Cancer. IARC monographs on the evaluation of carcinogenic risks to humans. Vol 46. Diesel and gasoline engine exhaust and some nitroarenes. Lyon: IARC, 1989.

2 Gubéran E, Usel M. Unusual mortality pattern among short term workers in the perfumery industry in Geneva. $\mathrm{Br} J$ Ind Med 1987;44:595-601.

3 Hill ID. Computing man years at risk. British Journal of Preventive Medicine 1972;26:132-4.

4 Breslow NE, Day NE. Statistical methods in cancer research. Vol II. The design and analysis of cohort studies. Lyon: International Agency for Research on Cancer, 1987:91-103.

5 Steenland $\mathrm{K}$. Lung cancer and diesel exhaust: a review. Am J Ind Med 1986;10:177-89.

6 Rickenbach M, Gutzwiller F, Wietlisbach V, Martin J, Epstein FH. Switzerland's participation in MONICA. Soz Praventivmed 1985;30:95-9.

7 Obradovic M, Fioretta G, Raymond L. Incidence des cancers gastriques et colo-rectaux dans les populations latines vivant à Genève. In: Epidemiologie du cancer dans les pays de langue latine. Lyon: International Agency for Research on Cancer, 1990:161-8. (Technical report series No 7.)

8 Balarajan R, McDowall ME. Professional drivers in London: a mortality study. Br J Ind Med 1988;45:483-6.

9 Carstensen JM, Pershagen G, Eklund G. Smoking-adjusted incidence of lung cancer among Swedish men in different occupations. Int J Epidemiol 1988;17:753-8.

10 Benhamou S, Benhamou E, Flamant R. Occupational risk factors of lung cancer in a French case-control study. $\mathrm{Br} J$ Ind Med 1988;45:231-3.

11 Buiatti E, Kriebel D, Geddes M, Santucci M, Pucci N. A case control study of lung cancer in Florence, Italy. I Occupational risk factors. $J$ Epidemiol Community Health 1985;39:244-50.

12 Hayes RB, Thomas T, Silverman DT, et al. Lung cancer in motor exhaust-related occupations. Am J Ind Med 1989;16: 685-95.

13 Zahm SH, Brownson RC, Chang JC, Davis JR. Study of lung cancer histologic types, occupation and smoking in Missouri. Am J Ind Med 1989;15:565-78.

14 Boffetta P, Harris RE, Wynder EL. Case-control study on occupational exposure to diesel exhaust and lung cancer risk. Am J Ind Med 1990;17:577-91.

15 Registrar General. Decennial supplement for Great Britain, 1979 80, 1982-83. Occupational mortality. London: HMSO, 1986.

16 Stellman SD, Boffetta P, Garfinkel L. Smoking habits of 800,000 American men and women in relation to their occupations. $\mathrm{Am}$ $J$ Ind Med 1988;13:43-58.

17 Damber L, Larsson LG. Professional driving, smoking, and lung cancer: a case referent study. $\mathrm{Br} J$ Ind $\mathrm{Med} 1985 ; 42$ : 246-52.

18 Morton WE, Treyve EL. Histologic differences in occupational risks of lung cancer incidence. Am J Ind Med 1982;3:441-57. 
19 Ives JC, Buffler PA, Greenberg SD. Environmental associations and histopathologic patterns of carcinoma of the lung: the challenge and dilemma in epidemiologic studies. Am Rev Respir Dis 1983;128:195-209.

20 International Agency for Research on Cancer. IARC monographs on the evaluation of carcinogenic risks to humans. Volume 44. Alcohol drinking. Lyon: IARC, 1988.

21 Nomura A. Stomach. In: Schottenfel D, Fraumeni JF. Cancer epidemiology and prevention. Philadelphia: WB Saunders, 1982:624-37.

22 Registrar General. Decennial supplement for England and Wales 1970-1972. Occupational mortality. London: HMSO, 1978.

23 Ames RG. Gastric cancer in coal miners: some hypotheses for investigation. J Soc Occup Med 1982;32:73-81.

24 Coggon D, Barker DJP, Cole RB. Stomach cancer and work in dusty industries. Br J Ind Med 1990;47:298-301

25 Garabrant DH, Peters JM, Mack TM, Bernstein L. Job activity and colon cancer risk. Am J Epidemiol 1984;119:1005-14.
26 Vena JE, Graham S, Zielezny M, Swanson MK, Barnes RE, Nolan J. Lifetime occupational exercise and colon cancer. $A m$ $J$ Epidemiol 1985;122:357-65.

27 Vena JE, Graham S, Zielezny M, Brasure J, Swanson MK. Occupational exercise and risk of cancer. Am J Clin Nutr 1987;45:318-27.

28 Gerhardsson M, Norell SE, Kiviranta H, Pedersen NL, Ahlbom A. Sedentary jobs and colon cancer. Am J Epidemiol 1986;123: 775-80.

29 Freudenheim JL, Graham S, Marshall JR, Haughey BP, Wilkinson G. A case-control study of diet and rectal cancer in Western New York. Am J Epidemiol 1990;131:612-24.

30 Siemiatycki J, Gérin M, Stewart P, Nadon L, Dewar R, Richardson $L$. Associations between several sites of cancer and ten types of exhaust and combustion products. Scand $J$ Work Environ Health 1988;14:79-90.

Accepted 23 September 1991

\section{Vancouver style}

All manuscripts submitted to the $B r J$ Ind Med should conform to the uniform requirements for manuscripts submitted to biomedical journals (known as the Vancouver style).

The $B r J$ Ind Med, together with many other international biomedical journals, has agreed to accept articles prepared in accordance with the Vancouver style. The style (described in full in $\mathrm{Br}$ Med J, 24 February 1979, p 532) is intended to standardise requirements for authors.

References should be numbered consecutively in the order in which they are first mentioned in the text by Arabic numerals above the line on each occasion the reference is cited (Manson ${ }^{1}$ confirmed other reports $\left.{ }^{2-5} \ldots\right)$. In future references to papers submitted to the $B r J$ Ind Med should include: the names of all authors if there are six or less or, if there are more, the first three followed by $e t$ al; the title of journal articles or book chapters; the titles of journals abbreviated according to the style of Index Medicus; and the first and final page numbers of the article or chapter.

Examples of common forms of references are:

1 International Steering Committee of Medical Editors. Uniform requirements for manuscripts submitted to biomedical journals. Br Med J 1979;1:532-5.

2 Soter NA, Wasserman SI, Austen KF. Cold urticaria: release into the circulation of histamine and eosino-phil chemotactic factor of anaphylaxis during cold challenge. N Engl J Med 1976;294:687-90.

3 Weinstein L, Swartz MN. Pathogenic properties of invading micro-organisms. In: Sodeman WA Jr, Sodeman WA, eds. Pathologic physiology: mechanisms of disease. Philadelphia: W B Saunders, 1974:457-72. 